\title{
STANDING TO RAISE CONSTITUTIONAL ISSUES RECONSIDERED, CONSIDERED
}

\author{
PATRICK KEYZER
}

\section{Introduction}

In 2005, Simon Evans and Stephen Donaghue wrote: ${ }^{1}$

One version of Australian constitutionalism involves a conception of the rule of law in which the courts sit at the centre and can be called on to rule on any or all constitutional disputes. This approach, which implicitly requires a generous approach to standing, is manifest in the High Court's strong commitment to ensuring that the validity of governmental action can be tested against constitutional (and, indeed, legislative) limits. ${ }^{2}$

Evans has contributed an article to this volume that restates this argument and develops it further. Evans now stresses the need for 'reform' of standing rules as well. Evans' article also offers a critique of my recent book Open Constitutional Courts. 3 This article offers a comment on Evans' arguments, and also responds to some of his criticisms of the theorising and reform agenda set out in Open Constitutional Courts.

\section{The practical operation of standing rules}

Evans and I have taken different methodological approaches in our analysis of standing. Evans' approach is purely doctrinal: he invokes the rule of law doctrine and argues that standing requirements should not be insisted on by courts if review of government action would not otherwise take place. My approach is both sociolegal and doctrinal: I analyse the practical operation of standing rules in their social

\footnotetext{
* Professor of Law and Director of the Centre for Law, Governance and Public Policy, Bond University.

1 See Simon Evans and Stephen Donaghue, 'Standing to Raise Constitutional Issues in Australia' in Richard S Kay (ed), Standing to Raise Constitutional Issues (Bruylant, 2005) 115, 137; and at greater length, Simon Evans and Stephen Donaghue, 'Standing to Raise Constitutional Issues in Australia' in Gabriël A Moens and Rodolphe Biffot (eds), The Convergence of Legal Systems in the 21st Century: An Australian Approach (CopyRight Publishing, 2002) 53, 97-8.

2 Evans and Donaghue, 'Standing to Raise Constitutional Issues in Australia' in Kay (ed), ibid, 142.

3 Patrick Keyzer, Open Constitutional Courts (Federation Press, 2010).
} 
context, then argue that standing rules should be abolished, and then show how the abolition of standing rules in constitutional cases is supported by a number of Australian constitutional doctrines, including (but not limited to) the rule of law doctrine.

I think that when the practical operation of standing rules is taken into account, it is difficult to accept Evans' contention that Australian jurisprudence has reflected a 'strong commitment to ensuring that the validity of governmental action can be tested'.

Two cases illustrate the problematic operation of standing rules in Australian constitutionalism: North Australian Aboriginal Legal Aid Service v Bradley (the NAALAS case $)^{4}$ and Croome v Tasmania. ${ }^{5}$ Since I will refer to them both later in the paper, and because it is necessary to have a sense of practical context when analysing standing rules, I need to go into them in some depth.

In the NAALAS case, the applicant, an aboriginal legal aid service, sought a declaration that the appointment of the Chief Magistrate of the Northern Territory was invalid. ${ }^{6}$ NAALAS argued that because the Northern Territory (the second respondent in the case) appointed Mr Bradley with a remuneration arrangement that expired in two years, that this placed him in a position of looming dependence on the executive government for the continuation of his remuneration - the antithesis of judicial independence. NAALAS argued that it is implicit in $\mathrm{Ch}$ III of the Constitution, which separates judicial power from legislative and executive power, that courts capable of exercising judicial power of the Commonwealth be and be seen to be independent and impartial tribunals. ${ }^{7}$

This argument was struck out by the Supreme Court of the Northern Territory. NAALAS appealed. ${ }^{8}$ The Northern Territory Court of Appeal allowed the appeal. The Northern Territory appealed. The High Court dismissed the appeal. The matter was remitted to the Supreme Court of the Northern Territory for trial, and then crossvested to the Federal Court.

On each of these occasions the Northern Territory, the second respondent in the case, objected to the standing of NAALAS. In the Federal Court and in the Full Federal

\footnotetext{
4 (2004) 218 CLR 146.

5 (1997) 191 CLR 119.

6 For further details, see Patrick Keyzer, 'Judicial Independence in the Northern Territory:

Are Undisclosed Remuneration Arrangements Repugnant to Chapter III of the Constitution?' (2004) 32 University of Western Australia Law Review 30.

7 (2004) 218 CLR 146, 163.

8 Keyzer, above n 3, 6-13.
} 
Court - after the High Court had said that the submissions advanced by NAALAS were arguable - the Northern Territory said that NAALAS had no standing to seek a declaration. Invoking the High Court's jurisprudence relating to standing, the Northern Territory said that NAALAS had no interest in the constitutional questions it raised, and that their interest was no greater than any ordinary member of the public. The Northern Territory government argued that NAALAS was a 'busybody' that stood to gain nothing from the proceedings except the satisfaction of righting a wrong. The Government argued that NAALAS had no proprietary or pecuniary interest at stake in the matter. The Government argued that NAALAS had no 'special interest' in the matter, but only had a mere intellectual or emotional interest in it.

Standing was ultimately upheld, but: ${ }^{9}$

not until a five-round fight on this issue. NAALAS had to expend scarce and valuable resources to access constitutional justice, and took the risk throughout that it would be denied standing (and therefore liable to costs).

Importantly, the High Court's more recent decisions on standing have not unequivocally abandoned this test, and it continues to be asserted by governments in constitutional cases. ${ }^{10}$ This has been the case even where the would-be constitutional litigant had raised a serious, arguable question of constitutional law. And governments, which are well-funded litigants, can exploit the uncertainty surrounding standing rules to maximise their leverage over impecunious litigants. ${ }^{11}$

In Open Constitutional Courts I argue that people in Australia who raise a serious, arguable question of constitutional law should not have to pay for access to constitutional justice as if the operation of the rule of law is a privilege that has a price. $^{12}$

The NAALAS case is not an isolated example of the pathological operation of standing rules. In Croome $v$ Tasmania, standing rules were invoked by the Tasmanian

9 Ibid 13.

10 Davis v Commonwealth (1986) 68 ALR 18; Shop Distributive and Allied Employees Association v Minister for Industrial Affairs (SA) (1995) 183 CLR 552, 558; Bateman's Bay Local Aboriginal Land Council v Aboriginal Community Benefit Fund Pty Ltd (1998) 194 CLR 247; Truth About Motorways Pty Ltd v Macquarie Infrastructure Investment Management Ltd (2000) 200 CLR 591, 599; Re McBain; Ex parte Australian Catholic Bishops Conference (2002) 209 CLR 372; Combet v Commonwealth (2005) 224 CLR 494; Pape v Commissioner of Taxation (2009) 238 CLR 1, 13, 19, 68.

11 Keyzer, above n 3, 14-5.

12 Ibid 22-3, 40-5. 
government to deny constitutional justice to homosexual people seeking equality of treatment under the law. ${ }^{13}$

A relatively detailed account of the facts and context of Croome $v$ Tasmania is required to demonstrate how the denial of standing can impact on an identity-related (nonpecuniary) claim for constitutional justice. It also provides a backdrop for the consideration of the argument I develop in Open Constitutional Courts that standing rules should be removed so that people can realise their freedom of political communication within judicial review. It is important to understand that Croome's contested attempt to access constitutional justice was the final stage, and a necessary stage, in a long political campaign to advance the recognition of his rights under law; rights that concerned matters fundamental to his personal identity.

Croome $v$ Tasmania was the final stanza of a sustained political campaign for gay law reform in Tasmania during the late 1980s and early 1990s. ${ }^{14}$ Rodney Croome, along with other gay law students, formed GUSTO, the Gay University Students of Tasmania Organisation, and arranged a series of gay awareness talks. A law reform committee, the Tasmanian Gay Law Reform Group (TGLRG), mobilised to work out ways to attack Tasmanian laws that made male-to-male sexual intercourse a criminal offence. ${ }^{15}$ A national conference on AIDS was a catalyst for the expression of homophobic statements by a number of conservative politicians, and this galvanised the TGLRG. ${ }^{16}$ The association first applied to the Hobart City Council in October 1988 to set up a stall in the Salamanca Markets, a popular weekend market, to collect signatures for a petition to be placed before the Tasmanian Parliament, demanding reform. ${ }^{17}$ The Council refused permission on the basis that the Tasmanian Criminal

13 (1997) 191 CLR 119.

14 The political campaign leading up to the end of 1994 is chronicled in Miranda Morris, Pink Triangle: The Gay Law Reform Debate in Tasmania (University of New South Wales Press, 1995).

15 Sections 122 and 123 of the Tasmanian Criminal Code made it a criminal offence to engage in homosexual conduct. Section 122 of the Tasmanian Criminal Code formerly provided that: 'Any person who - (a) has sexual intercourse with any person against the order of nature; ... or (c) consents to a male person having sexual intercourse with him or her against the order of nature; is guilty of a crime.' Section 123 of the Code provided that: 'Any male person who, whether in public or private, commits any indecent assault upon, or other act of gross indecency with, another male person, or procures another male person to commit any act of gross indecency with himself or any other male person, is guilty of a crime'.

16 Morris, above n 14, 42.

17 Ibid. 


\section{STANDING TO RAISE CONSTITUTIONAL ISSUES RECONSIDERED, CONSIDERED}

Code made homosexual conduct a criminal offence. ${ }^{18}$ Permission was denied even though the applicants complied with every element of the markets regulation. ${ }^{19}$

Over the following weekends the TGLRG defied the ban and more and more people, gay and straight, came to the markets to demonstrate in favour of gay rights. ${ }^{20}$ By the fourth Saturday the police took action, arresting nine people who refused to leave the area after the Acting Town Clerk had read them regulations indicating that they were engaged in an unlawful trespass. ${ }^{21}$ On subsequent Saturdays over a period of about three months, some 130 people were arrested for trespass.22 Croome was arrested when he took steps to operate the stall, and arrested three more times subsequently. ${ }^{23}$ Ultimately, criminal charges were not pressed by the Hobart City Council, and the stall was allowed to remain, in spite of the fact that the stallholders advocated unlawful activity. ${ }^{24}$ In the meantime, the membership of the TGLRG swelled from about 30 to over 200. ${ }^{25}$ They continued their campaign for reform, including demonstrations and a high profile media campaign focusing on the issues and advocacy of gay law reform 'in every forum possible'. ${ }^{26}$

In July 1991 the Upper House of the Tasmanian Parliament refused to pass legislation repealing the anti-homosexual provisions of the Criminal Code. Nick Toonen, Rodney Croome's partner, made an application under the First Optional Protocol of the International Covenant on Civil and Political Rights to the United Nations Human Rights Committee for a determination that the Tasmanian law was in violation of international human rights law. The Committee unanimously decided that the repeal of the Tasmanian laws would provide an effective remedy for Toonen. ${ }^{27}$

18 Ibid 44.

19 Ibid.

20 Ibid 46.

21 Ibid.

22 Ibid.

23 Ibid 47.

24 Affidavit of Rodney Peter Croome, filed in Croome v Tasmania (1997) 191 CLR 119, 12 March 1996, copy on file with the author.

25 Morris, above n 14, 49.

26 Rodney Croome, 'Australian Gay Rights Case Goes To The United Nations' (1992) 2 Australian Gay and Lesbian Law Journal 55, 55. See also Morris, above n 14, 18: '(it was) for the TGLRG, a learning place for direct action'.

27 Toonen $v$ Australia, Communication No 488/1992, noted in Submissions of the Human Rights and Equal Opportunity Commission, filed in Croome v Tasmania (1997) 191 CLR 119, Paragraph 16(e), copy on file with the author. The Committee held that the provisions were contrary to Articles 2(1) and 17 of the International Covenant on Civil and Political Rights. 
Implementing the favourable UNHRC decision, the Commonwealth government passed legislation overriding the Tasmanian law in 1993. However Tasmania took no steps to repeal the provisions and continued to refer to them to justify the imposition of restrictions on civil rights. And Tasmanian officials continued to express openly homophobic attitudes. For example, in March 1995 the State Attorney-General refused permission to the first Tasmanian Gay and Lesbian Film and Video Festival to view unclassified films on the basis that the provisions of the Criminal Code reflected a State government policy that 'certain sorts of conduct are not acceptable in Tasmania' and the films for which permission was sought 'related to homosexual and lesbian lifestyles and therefore after very careful consideration it was decided we wouldn't give that exemption' ${ }^{28}$

Croome then took steps to challenge the constitutional validity of the Tasmanian law. Since the Tasmanian Parliament was unwilling to change the laws, Croome's constitutional challenge was the final step it could take in his political campaign. It was the only option left to him and the homosexual people he represented to get rid of the law, since they could not attract majority support for their cause in the electorate. Croome filed an application for a declaration that while their sexual intercourse was prohibited by the Tasmanian provisions, it was protected by the superior Commonwealth law. ${ }^{29}$ It was argued that the Tasmanian provisions were therefore invalid to the extent of their inconsistency pursuant to s 109 of the Commonwealth Constitution. ${ }^{30}$

Tasmania resisted Croome's claim on a number of grounds, including the ground that he had no standing to seek declaratory relief. Tasmania argued that Croome had no material interest in the question of constitutional validity, but only a mere intellectual or emotional interest in it. Tasmania's second principal argument was that because Tasmania had made no attempt to prosecute the law, the High Court should not be called on to answer a purely hypothetical question. The Tasmanian Director of Public Prosecutions filed affidavits stating that no charges had been laid against either of the plaintiffs under the relevant provisions of the Code, and that he was not aware of any current investigations into alleged breaches of either of those

28 Affidavit of Rodney Peter Croome, filed in Croome v Tasmania (1997) 191 CLR 119, 12 March 1996, citing a radio interview with Tasmanian Attorney-General Ron Cornish on 22 March 1995.

29 This type of $\mathrm{s} 109$ argument was advanced in $R v$ Brisbane Licensing Court; Ex parte Daniell (1920) 28 CLR 23, 29; Colvin v Bradley Bros Pty Ltd (1943) 68 CLR 151, 158, 161; Mabo v Queensland (1988) 166 CLR 186. See further Patrick Keyzer, Principles of Australian Constitutional Law (LexisNexis, $3^{\text {rd }}$ ed, 2010), Chapter 21.

30 Outline of Argument for the Plaintiffs, filed in Croome v Tasmania (1997) 191 CLR 119, paras 9 and 10, copy on file with the author. 


\section{STANDING TO RAISE CONSTITUTIONAL ISSUES RECONSIDERED, CONSIDERED}

sections by either plaintiff. ${ }^{31}$ The Director of Public Prosecutions had received a letter from the Legal Officer of the Tasmania Police calling upon him to consider whether a prosecution should be laid against the plaintiffs for breaches of the Code. But even though he had responded with a report that there was sufficient evidence to justify the exercise of the discretion to prosecute, he decided against that course. ${ }^{32}$

The reason why the Director of Public Prosecution's decision not to prosecute Croome and Toonen was so important to the question of standing under the law that then applied was that without a prosecution it was unclear whether Croome or Toonen could commence an action in the High Court seeking a declaration that the Tasmanian provisions were invalid. When Croome commenced an action in the High Court to that end, Tasmania entered a conditional appearance to object to the jurisdiction of the Court and argued that the writ and the statement of claim should be set aside because the action did not give rise to a "matter" within s 76 of the Constitution (that is, there was no legal dispute between parties); as (1) the proceedings were an abuse of process of the Court because the plaintiffs sought to obtain the opinion of the Court without any right or duty of any body or person being involved (that is, the Court was being invited to answer an 'abstract question' or deliver an 'advisory opinion'); and (2) on the basis that the plaintiffs did not have a special interest in the subject matter of the action sufficient to support standing to sue for a declaration. ${ }^{33}$ Tasmania argued that Croome was only raising a hypothetical question about the validity of the Tasmanian law, and would not have a sufficient interest in the question until the law had been enforced by the State. It was argued that a 'matter' for the purposes of Ch III of the Constitution could only arise when the law was enforced, and the rights, duties or liabilities of the citizen were in issue in litigation that was pending in that sense. Tasmania said they did not intend to prosecute Croome. There was, on this view, only a hypothetical question to be determined, no legal dispute, and therefore no standing.

31 Affidavit of Damian John Bugg, para 2, filed in Croome v Tasmania (1997) 191 CLR 119, 24 November 1995.

32 Affidavit of Damian John Bugg, 21 December 1995, filed in Croome v Tasmania (1997) 191 CLR 119. After Croome was interviewed by police in relation to his statutory declaration, he was not informed by the Police or the Director of Public Prosecutions that a policy had been adopted not to subject him to prosecution. Newspaper reports (The Examiner, 29 October 1994, 2; The Advocate, 29 October 1994; The Saturday Mercury, 29 October 1994, 1) published substantial portions of an advice produced by the Director that indicated that there was sufficient evidence of criminal conduct to satisfy normal tests of gravity before prosecutions were commenced (Affidavit of Rodney Peter Croome, filed in Croome v Tasmania (1997) 191 CLR 119, 12 March 1996).

33 Summons of 9 February 1996, copy on file with the author. 
Croome's counsel argued that the inconsistency between the provisions of the Tasmanian Criminal Code and the Commonwealth legislation and the conduct of the plaintiffs constituted a matter, and therefore a justiciable suit. ${ }^{34}$ Adjudication on the question of inconsistency would involve a right or privilege or protection given by law. ${ }^{35}$ The inconsistency of laws created a violation of a positive law. ${ }^{36}$ The question raised by the plaintiffs was real, not merely hypothetical. The inconsistency of laws arose out of circumstances that, according to the uncontradicted evidence of the plaintiffs, had arisen and would continue to arise. The plaintiffs had their reputation tarnished as law-breakers and they continued to face possible prosecution. The decision not to prosecute the plaintiffs was made upon grounds specific to the particular offences admitted, and the plaintiffs enjoyed no ongoing immunity from prosecution. ${ }^{37}$ Croome was entitled to know which legislative regime regulated his conduct, whether he could continue to engage in homosexual conduct, and according standing would further the purpose of s 109 of the Constitution. ${ }^{38}$

The Commonwealth Attorney-General argued in support of Croome that it would be absurd to require that people wait to be prosecuted before being able to challenge the constitutional validity of legislation subjecting people to compulsive powers. ${ }^{39}$ Furthermore, the plaintiffs argued that they had a special interest in the matter, derived from their self-identification as homosexual males, their notoriety in Tasmania as campaigners for the repeal of the provisions of the Code, the widespread publicity given to the report of the Director of Public Prosecutions in which both of them were identified as prima facie guilty of criminal offences, under ongoing threat of prosecution, the restrictions imposed by law on their ability to sign leases (which typically include a 'no illegal behaviour on the premises' clause), and the link

34 Plaintiff's Outline of Argument, para 12, copy on file with the author.

35 In re Judiciary and Navigation Acts (1921) 29 CLR 257, 266; Polyhukovich v The Commonwealth (1991) 172 CLR 501, 615.

36 Plaintiff's Outline of Argument, Paragraph 13, copy on file with the author; Polyhukovich v The Commonwealth (1991) 172 CLR 501, 615.

37 Written Submissions of the Attorney-General for the Commonwealth (Intervening in support of the Plaintiffs), para 2.4, copy on file with the author.

38 Cf Plaintiff's Outline of Argument, para 23, copy on file with the author. See also Written Submissions of the Attorney-General for the Commonwealth (Intervening in support of the Plaintiffs), para 2.5, copy on file with the author.

39 Written Submissions of the Attorney-General for the Commonwealth (Intervening in support of the Plaintiffs), para 2.6, copy on file with the author, citing Colonial Sugar Refining Co Ltd v Attorney-General (Cth) (1912) 15 CLR 182, 193, 202-5, and later referring to Oil Basins Ltd v Commonwealth (1993) 178 CLR 643, 648-9. 


\section{STANDING TO RAISE CONSTITUTIONAL ISSUES RECONSIDERED, CONSIDERED}

between the provisions of the Code and the discrimination to which they were subjected. ${ }^{40}$

The Human Rights and Equal Opportunity Commission, intervening in support of the plaintiffs, submitted that where an individual's personal rights have been recognised in international law, especially where that recognition is in respect of the existence of human rights, then that may of itself establish that an individual has a 'special interest' in relation to domestic litigation on the same matter. ${ }^{41}$

The High Court rejected Tasmania's objections to standing, with three of the six judges sitting holding that Croome had standing because he might be prosecuted in the future for something he had done, ${ }^{42}$ and the other three judges holding that Croome had standing because he might be prosecuted for something that might be unconstitutional. ${ }^{43}$

The difference between these two positions may seem small, but it is a crucial difference. ${ }^{44}$ It is palpably unfair to expect people to take the risk of criminal prosecution, conviction and the possible penal consequence of imprisonment before they can raise a constitutional question..$^{45}$ Although Tasmania had declined to charge Croome with offences under the Criminal Code, the Director of Public Prosecutions had identified Croome as being prima facie guilty of criminal offences. Croome was therefore under an ongoing threat of prosecution and his reputation was tarnished as

40 Plaintiff's Outline of Argument, para 32; Affidavit of Rodney Croome paras 3 - 9, Affidavit of Nicholas Toonen, paras $4-11$, copies on file with the author.

41 Submissions of the Human Rights and Equal Opportunity Commission, para 16(d), copy on file with the author.

42 Croome v Tasmania (1997) 191 CLR 119, 127 (Brennan CJ, Dawson and Toohey JJ): ‘We do not wish now to assent to the broad proposition that any person who desires or intends to act in contravention of a law has, by reason merely of that desire or intention, a cause of action to seek a declaration of invalidity of the law'. See also Colonial Sugar Refining Co Ltd v Attorney-General for the Commonwealth (1912) 15 CLR 182, 220, 226; W \& A McArthurv Queensland (1920) 28 CLR 530, 560; Luna Park Ltd v Commonwealth (1923) 32 CLR 596, 600.

43 Croome v Tasmania (1997) 191 CLR 119, 137-8 (Gaudron, McHugh and Gummow JJ).

44 The US courts are not prepared to go this far. If the States of the United States do not seek to enforce their homophobic statutes then 'no injury takes place' and there is no standing to seek redress: see Christopher Leslie, 'Standing In The Way Of Equality: How States Use Standing Doctrine to Insulate Sodomy Laws from Constitutional Attack' (2001) Wisconsin Law Review 29.

45 Written Submissions of the Attorney-General for the Commonwealth (Intervening in support of the Plaintiffs), para 2.6, copy on file with the author, citing Colonial Sugar Refining Co Ltd v Attorney-General (Cth) (1912) 15 CLR 182, 193, 202-5, and later referring to Oil Basins Ltd v Commonwealth (1993) 178 CLR 643, 648-9. 
a law-breaker. Furthermore, restrictions were imposed by law on Croome's ability to sign leases (which typically include a 'no illegal behaviour on the premises' clause). In light of these significant matters, it certainly seems that the criminal prosecution requirement requires reconsideration. ${ }^{46}$ Is it really necessary for a person to be imprisoned, subject to an imminent penalty or to live under the threat of prosecution before a constitutional case can be commenced ${ }^{47}$ And to reinforce an earlier point, is it really necessary to require people to risk their personal finances to advance such questions? ${ }^{48}$ These important questions have not been resolved by the High Court's recent cases on standing.

With a deeper appreciation of the practical operation of standing rules in a few constitutional cases, and a richer appreciation of the impact of standing rules on the capacity of marginalised people to realise their identity, it is difficult to conclude that Australian jurisprudence has reflected a 'strong commitment to ensuring that the validity of governmental action can be tested'.

\section{Freedom of political communication}

In Open Constitutional Courts I argue that the constitutional doctrine of freedom of political communication should apply within judicial review because an application for judicial review can sensibly be characterised as a type of anti-government expression. ${ }^{49}$ When a person files an application in court that particular legislation may be constitutionally invalid, that applicant is opposing government policy as it is reflected in parliamentary law. If expressing dissent from government policy is prima

46 See further Graham Taylor, 'Standing To Challenge The Constitutionality Of Legislation' in Leslie Stein (ed), Locus Standi (Lawbook, 1979), 161, citing Colonial Sugar Refining Co Ltdv Attorney-General for the Commonwealth (1912) 15 CLR 182, 220, 226.

47 Tasmania conceded that if they lost their arguments on abstract questions, justiciability and standing that the law would be found invalid to the extent of its inconsistency in a subsequent s 109 case.

48 In an interview I conducted with Rodney Croome in 2002 I asked him what his reaction was to advice from his legal counsel about the nature and operation of these rules and whether he feared an adverse costs order (probably in the order of $\$ 50-100,000$ if he lost) and he said "we just had to do it" (Personal communication, 10 October 2002). Croome said that he started the constitutional action because he wanted to protect himself and other homosexuals from the fear of prosecution under the criminal law and to suppress vilification.

49 Robert L Tsai, 'Conceptualizing Constitutional Litigation as Anti-Government Expression: A Speech-Centered Theory of Court Access', (2002) 51 American University Law Review 848. See also Christopher J Peters, 'Adjudicative Speech and the First Amendment' (2004) 51 University of California Los Angeles Law Review 705, 712-3; Barbara Arco, 'When Rights Collide' (1998) 52 University of Miami Law Review 587. 


\section{STANDING TO RAISE CONSTITUTIONAL ISSUES RECONSIDERED, CONSIDERED}

facie protected communication, then so are expressions of dissent from government policy via constitutional proceedings. If this characterisation is correct, then it would follow that the hearing of the application and all of the activities that are sufficiently connected with that application could be also be characterised as being incidental to anti-government expression. (It would also follow that applications for intervention or for amicus curiae status in respect of an application for judicial review could properly be characterised as being incidental to anti-government expression).

The fact that an application for judicial review of legislative action is also accompanied by a request for a legal dispute to be resolved (that it is a 'matter') does not alter the character of the application as an expressive act about governmental affairs. It may have an additional character then, but the application does not, for that reason only, cease to involve anti-government expression. Indeed, constitutional matters are unavoidably concerned with political and governmental affairs..$^{50}$

In Open Constitutional Courts I argue that standing rules are inconsistent with the freedom of political communication because the net effect of these rules is to restrict access to constitutional justice for people and associations who want to express their political dissent; and these restrictions are based on identity, wealth and capacity to attract government support. These rules burden freedom of political communication via judicial review, and they are not reasonably appropriate and adapted to serve a legitimate end in a manner which is compatible with the maintenance of the constitutionally prescribed system of representative government. ${ }^{51}$

Evans responds to this analysis by saying that:

the standing rules may well not be reasonably appropriate and adapted to protecting courts against baseless actions as Keyzer argues. But that is not their only or most important purpose. Alternative rationales include upholding 'the primacy of the political process as a constitutional constraint' by diverting 'constitutional questions involving broad social rights or interests' to the legislative and political process, deflecting the 'decision when and in what circumstances to enforce public law' to the Executive, improving the quality of judicial decision-making by limiting it to situations where the legal situation of the parties will be affected, and even preventing the diversion of the courts' limited resources to public interest actions [at the expense of] their ability to protect individuals and minority groups from oppressive or discriminatory government action.' The fact that better rules

50 Richard A Posner, 'Foreword: A Political Court (The Supreme Court 2004 Term)' (2005) 119(1) Harvard Law Review 31, 40-1.

51 Keyzer, above n 3, 124-36. 
might be found (or created) is not a reason for concluding that existing tools are inconsistent with the Constitution (references omitted).

The problem with taking this argument too far is that it cordons off constitutional discourse from the direct influence of dissenters. It would be curious that constitutional free speech can operate within political discourse to authorise the criticism of politicians, but not within a subset of political discourse that enables the effectual challenge of the legislation that is the most significant product of those politicians.

Finally, this paragraph of Evans' article, which defends the denial of standing for a variety of reasons, is a bit surprising given his repeatedly-stated desire for 'reform' of standing rules. I return to this point below.

\section{The rule of law doctrine as a foundational rationale for the relaxation of standing}

The notion that the 'rule of law doctrine' justifies the provision of standing is not new. The argument has been made for many years by judges and scholars, and Simon Evans and I are just two of many who have explored the proposition. ${ }^{52}$

Even a thin account of the rule of law in a system characterised by a separation of judicial power and a constitutionally entrenched guarantee of judicial review would require that any person with a serious, arguable constitutional grievance would be able to have that grievance heard in court. But if the rule of law requires that courts 'can be called on to rule on any or all constitutional disputes', as Evans (and Donaghue) have said, then how can this justify only a 'generous' approach to standing? And when should the generosity be extended?

Evans states that:

The special interest requirement is particularly apt for evaluating standing to challenge laws that regulate conduct by imposing duties. It should continue to apply in those contexts, ensuring that challenges are as concrete as possible. It is far less apt to keep modern federal government within its powers when it regulates conduct by expenditure, intergovernmental agreements, codes of conduct and licensing agreements, which by their very nature are likely to lack the direct effect on rights and interests required by the traditional law of standing. When the choice is between more abstract review and no review of

52 See, eg, Ex parte National Federation of Self-Employed and Small Businesses Ltd [1982] AC 617, 653G-H; Attorney-General (Vic); Ex rel Black v The Commonwealth (1981) 146 CLR 493, 634: 'Any one of the people of the Commonwealth has the standing to proceed in the courts to secure the observance of constitutional guarantees'. See also Peter Johnston, 'Government Standing Under the Constitution' in Leslie Stein (ed), Locus Standi (Lawbook, 1979). 


\section{STANDING TO RAISE CONSTITUTIONAL ISSUES RECONSIDERED, CONSIDERED}

government action, the rule of law counsels in favour of the former (references omitted).

If the rule of law doctrine has a generative capacity, as Evans has stated in the concluding sentence of his article, how does it generate anything? The rule of law doctrine, at least as it is presently formulated in Australian constitutional jurisprudence, requires nothing more than that the judicial branch of government determines the constitutional validity of legislative action in Australia. Unless the rule of law doctrine affords an entitlement to know the law, or an entitlement is located in one or more additional constitutional doctrines as I have argued in Open Constitutional Courts, the rule of law doctrine does not take us very far. The problem with Evans' argument is that he does not explain why the rule of law doctrine ought to have the effect outlined in the quote above.

In His Honour's contribution to this volume, Sir Anthony Mason writes: ${ }^{53}$

In a society that is governed by a constitution it is imperative that its provisions be observed. Compliance with the provisions of the Australian Constitution is central to the rule of law.

I agree. That is why one of the arguments I advance in Open Constitutional Courts is that the invocation of standing tests as an obstacle to access to constitutional justice is inconsistent with the rule of law when a person raises a serious, arguable question of constitutional law.

Finally, Evans argues that the rule of law doctrine is sufficient to justify reform of standing, and there is no need to consider the utility of invoking other constitutional doctrines:

the implied freedom of political communication does not require open standing: the freedom operates in a constitutional context in which judicial power is exercised by courts only in 'matters'. The common law of standing must yield to constitutional imperatives (whether characterised as the implied freedom of political communication or as a separate set of implications drawn from Ch III requiring access to the courts to conduct constitutional litigation), but those imperatives are delimited by the Constitution itself and not by a free-standing concept of access to justice.

I find it difficult to understand why the rule of law doctrine should be cordoned off from other doctrines of Australian constitutionalism in the search for a rationale for reforming (or even abolishing) standing in constitutional cases. It is difficult to understand why the reform of standing rules should be anchored in the rule of law doctrine but not other Australia constitutional doctrines. Judicial review and

53 Sir Anthony Mason, in this volume. 
constitutional free speech need not be seen as doctrines operating disjunctively, but rather as complementary doctrines in our system of representative government, operating in harmony to achieve important and mutually-reinforcing goals (including the ideal of popular sovereignty). ${ }^{54}$

I should add that I did not argue in Open Constitutional Courts that there is a 'freestanding concept of access to justice' that should provide the touchstone for reform of standing rules.

\section{Abuse of process rules present an 'undemanding threshold'}

In Open Constitutional Courts I argue that if a person does not raise a serious, arguable question of constitutional law that they should not have access to constitutional justice. I argue that the courts can exclude would-be litigants who do not raise serious arguments by applying the rules governing abuse of process. Evans is not persuaded: 55

the law of standing currently insists on a more specific link between the challenger and the challenged law than that the challenger is a member of the polity in which the law operates. To accept open standing would obliterate the law of standing to raise constitutional issues, its place taken by the courts' residual powers to dismiss cases that are vexatious or an abuse of process. Beyond those undemanding thresholds, a collectively-held entitlement to know the state of the law would entitle any member of the polity to seek guidance from the courts on the constitutional validity of any executive or legislative action. Apart from the role of the Attorneys-General (who Keyzer rightly discounts as a safeguard of legality) I see nothing in the Australian tradition that supports this vision of constitutional adjudication as a general advisory function, open to all (references omitted).

In Open Constitutional Courts I argue that standing rules should be abolished in constitutional cases (or 'obliterated', if that expression is preferred), and that the rules governing abuse of process should be applied instead to discourage litigation that does not raise a serious, arguable question of constitutional law. I did not argue that Australian constitutional courts should have 'a general advisory function, open to all'. What I argued is that the courts ought not exclude a person from access to constitutional justice on the basis of who they are. Instead, the courts can exclude people from access to constitutional justice on the basis of what they have argued.

Evans says that the rules governing abuse of process are 'undemanding thresholds'. That is inaccurate, and the NAALAS case demonstrates that. NAALAS had to contest

54 Tsai, above $\mathrm{n} 49,835$.

55 Simon Evans, in this volume. 
strike-out applications in the Supreme Court, Court of Appeal and High Court before the matter could go to trial. That is hardly evidence of an undemanding threshold.

\section{Has Evans offered a coherent case for 'reform'?}

In his contribution to this volume, Simon Evans argues that:

Rather than 'everyone has the right to know whether the law that governs someone is valid' it is 'there must be someone who can find out whether every government action is lawful'. This foundation speaks to the major problem with the special interest test: its requirement of a 'special interest' may ensure that litigation has a concreteness that is apt for the judicial process but it also opens the possibility that some government action is effectively unrestrained by law because the action has no direct and special effect on anyone's rights and interests (references omitted).

But while Evans identifies a 'major problem' with the 'special interest' test, and elsewhere in his paper says that standing rules (which include this test) are 'complex', characterised by 'invidious distinctions' and 'produce unnecessary uncertainty', Evans rather surprisingly goes on to argue that:

The special interest requirement is particularly apt for evaluating standing to challenge laws that regulate conduct by imposing duties. It should continue to apply in those contexts, ensuring that challenges are as concrete as possible. It is far less apt to keep modern federal government within its powers when it regulates conduct by expenditure, intergovernmental agreements, codes of conduct and licensing agreements, which by their very nature are likely to lack the direct effect on rights and interests required by the traditional law of standing. When the choice is between more abstract review and no review of government action, the rule of law counsels in favour of the former (references omitted).

Except for the last sentence (which immediately causes me to ask 'okay, but why?') this paragraph merely restates the status quo.

The special interest test that Evans favours in cases where people are challenging laws 'that regulate conduct by imposing duties' was identified in Australian Conservation Foundation $v$ Commonwealth.56 The ACF was incorporated under law, and its objects included concern to protect the environment. It received annual grants from the Minister for the Environment for its purposes, and it had previously performed the role of commenting on draft environmental impact statements in

56 While the case was strictly concerned with an administrative law issue, the judges referred to the principles of standing in constitutional and administrative law cases interchangeably: see Australian Conservation Foundation v Commonwealth (1980) 146 CLR 493. 
respect of proposed developments. Iwisaki, a company, proposed development of a resort and tourist area in Queensland, and the ACF sought judicial review of the legality of the development application, raising administrative and constitutional law points. Justice Aickin remarked that:

there is a clear majority of the Court for the proposition that unless a plaintiff is adversely affected in some way to an extent greater than the public generally he may not maintain an action for an injunction or a declaration in respect of either the validity of a statute or some breach by the executive government or statutory authorities. ${ }^{57}$

In other words, an interest in preserving the environment that is not grounded in an economic concern is not a 'special' interest and therefore is unworthy of protection. Justice Gibbs delivered a judgment that has often been cited since:

I would not deny that a person might have a special interest in the preservation of a particular environment. However, an interest, for present purposes, does not mean a mere intellectual or emotional concern. A person is not interested within the meaning of the rule, unless he is likely to gain some advantage, other than the satisfaction of righting a wrong, upholding a principle or winning a contest, if his action succeeds or to suffer some disadvantage, other than a sense of grievance or a debt for costs, if his action fails. A belief, however strongly felt, that the law generally, or a particular law, should be observed, or that conduct of a particular kind should be prevented, does not suffice to give its possessor locus standi. If that were not so, the rule requiring special interest would be meaningless. Any plaintiff who felt strongly enough to bring an action could maintain it. ${ }^{58}$

This test of standing plainly truncated the capacity of Australian constitutional law to accommodate claims for constitutional justice based on extra-material concepts of personal identity. This is plain from the NAALAS case and from the Croome case.

The High Court, having placed itself in the invidious position of having to decide whether an extra-material interest was merely intellectual or emotional, was shortly thereafter confronted by a test case involving the spiritual link between some aboriginal people and a particular area of land. In Onus $v$ Alcoa $L_{t d},{ }^{59}$ two Aboriginal women, members of the Gournditch-jmara people, traditional custodians of a particular area of land, sought an injunction to restrain Alcoa from interfering with aboriginal relics on the site of a proposed aluminium smelter. The Court drew an

57 (1980) 146 CLR 493, 508 (Aickin J).

58 Australian Conservation Foundation v The Commonwealth (1980) 146 CLR 493, 530 (Gibbs J).

59 (1981) 149 CLR 27, noted by Robyn Glindemann, 'Standing To Sue For Environment Protection: A Look At Recent Changes' (1996) 24 Australian Business Law Review 246, 247-8. 


\section{STANDING TO RAISE CONSTITUTIONAL ISSUES RECONSIDERED, CONSIDERED}

untenable distinction between an intellectual interest, which by itself would not support standing, and a spiritual interest, which would. Justice Gibbs, who had given the leading judgment on standing in the Australian Conservation Foundation case, offered the following justification for the distinction:

The position of a small community of Aboriginal people of a particular group living in a particular area which that group has traditionally occupied, and which claims an interest in relics of their ancestors found in that area, is very different indeed from that of a diverse group of white Australians associated by some common opinion on a matter of social policy which might equally concern any other Australian. ${ }^{60}$

This statement yields a number of remarkable syntagms: white/black, many/few, particular interest/general interest, sufficient interest/insufficient interest, traditional interest/non-traditional interest. Most striking is Gibbs J's presumption that all of the members of the ACF were white - and that this 'fact' helped provide a satisfactory basis for distinguishing Onus $v$ Alcoa from the ACF case. The Court was plainly anxious to ensure protection of sacred sites pursuant to the legislation in issue. But the comments quite clearly demonstrate how standing determinations involve value judgments by High Court judges that provide only some people with access to constitutional justice.

If 'reform' is necessary, as Evans says throughout his chapter, it is unclear what his reform agenda is. In his discussion of my freedom of communication argument, Evans remarks:

standing rules may well not be reasonably appropriate and adapted to protecting courts against baseless actions as Keyzer argues. But that is not their only or most important purpose. Alternative rationales include upholding 'the primacy of the political process as a constitutional constraint' by diverting 'constitutional questions involving broad social rights or interests' to the legislative and political process, ${ }^{61}$ deflecting the 'decision when and in what circumstances to enforce public law' to the Executive, ${ }^{62}$ improving the quality of judicial decision-making by limiting it to situations where the legal situation of the parties will be affected, ${ }^{63}$ and even preventing 'the diversion of the courts' limited resources to public interest actions [at the expense of] their ability to protect individuals and minority groups from oppressive or discriminatory government action.' The fact that better rules

\footnotetext{
60 (1981) 149 CLR 27, 37 (Gibbs J).

61 Ibid 177.

62 Bateman's Bay (1998) 194 CLR 247, 278 [86] (McHugh J).

63 Mellifont v Attorney General (Queensland) (1991) 173 CLR 289, 318 (Brennan J).
} 
might be found (or created) is not a reason for concluding that existing tools are inconsistent with the Constitution (references omitted).

It is difficult to reconcile repeated references to the need to reform standing rules with these comments. The purpose of reform is to find (and even create) better rules. Even if it were accepted that any of these grounds for refusing judicial review were appropriate (which I am prepared to accept as an abstract proposition, for the sake of the present argument), Evans has failed to demonstrate why standing rules are needed: rules governing justiciability and abuse of process could be invoked to achieve some or all of these objectives.

\section{Conclusion}

Evans contends that Open Constitutional Courts offers a 'competing' approach to the notion that the rule of law doctrine justifies reform of standing rules, and that competing principle is 'access to constitutional justice'. This phrase seems to have caused unnecessary confusion. For mine, the phrase 'access to constitutional justice' means no more and no less than having an opportunity to have a matter heard. 'Access to constitutional justice' is not a paradigm. Access to constitutional justice is the cart, not the horse.

Simon Evans and I agree that reform of standing rules is warranted. We largely agree on the problems with these rules. But Evans has failed to offer a persuasive agenda for reform. That is because Evans has failed to provide a satisfactory answer to the fundamental question considered in Open Constitutional Courts: why should a person with a serious, arguable question of constitutional law to raise in court ever be denied access to constitutional justice on the ground of a lack of standing? That denial of standing thwarts the realisation of equal dignity under the law, is inconsistent with Australian constitutionalism, and is no longer acceptable. 